\title{
Decomposition and Nutrient Release of Selected Cereal and Legume Crop Residues
}

\author{
Paul Anguria ${ }^{1}$, George N. Chemining'wa ${ }^{2}$, Richard N. Onwonga ${ }^{3} \&$ Michael A. Ugen $^{1}$ \\ ${ }^{1}$ National Semi Arid Resources Research Institute (NaSARRI), Soroti, Uganda \\ ${ }^{2}$ Department of Plant Science and Crop Protection, University of Nairobi, Nairobi, Kenya \\ ${ }^{3}$ Department of Land Resource Management and Agricultural Technology, University of Nairobi, Nairobi, \\ Kenya
}

Correspondence: Paul Anguria, National Semi Arid Resources Research Institute, Serere, P.O. Box 56, Soroti, Uganda. E-mail: paulanguria@yahoo.com

$\begin{array}{ll}\text { Received: February 7, } 2017 & \text { Accepted: April 6, } 2017 \quad \text { Online Published: May 15, } 2017 \\ \text { doi:10.5539/jas.v9n6p108 } & \text { URL: https://doi.org/10.5539/jas.v9n6p108 }\end{array}$

\begin{abstract}
Crop residues have the potential to enhance soil fertility, but this is dependent on their biochemical quality. A study was conducted at the National Semi-Arid Resources Research Institute-Serere, Uganda to determine the chemical composition, nutrient release patterns and rates of selected crop residues. The design used was randomized complete block design with four replications. The treatments comprised of $20 \mathrm{~g}$ of finger millet, sorghum, cowpea and groundnut crop residues. Finger millet had the highest initial C (36.28\%) and N (3.46\%), cowpea had the highest initial $\mathrm{P}(0.60 \%)$ and $\mathrm{Ca}(0.30 \%)$ and groundnut shells had significantly the highest initial K (1.01\%). Finger millet husks with the lowest carbon/nitrogen ratio, had significantly the highest rate of dry matter disappearance and nutrient release, while groundnut shells with the highest carbon/nitrogen and carbon/phosphorus ratios had significantly the lowest nutrient release and dry matter disappearance rates. At the end of incubation, finger millet husks had significantly the lowest $\mathrm{N}(0.29 \%)$ and $\mathrm{C}(10.22 \%)$, while cowpea husks had the lowest $\mathrm{P}(0.27 \%), \mathrm{K}(0.18 \%)$ and $\mathrm{Ca}(0.27 \%)$. Nutrient release and dry matter disappearance rates of crop residues occurred in the order of $\mathrm{N}>\mathrm{K}>\mathrm{P}>\mathrm{Ca}$ and finger millet husks $>$ cowpea husks $>$ sorghum husks $>$ groundnut shells, respectively. This study has demonstrated that finger millet husks released nutrients faster and this is beneficial for early planted crops, while groundnut shells released nutrients slowly which is appropriate for long term availability of plant nutrients.
\end{abstract}

Keywords: carbon/nitrogen ratio, crop residues, incubation and nutrient release rates

\section{Introduction}

Crop yields in north eastern Uganda are highly variable and substantially affected by low levels of soil fertility and moisture retention (Engoru et al., 2001; Elmahdi et al., 2007). Soils in north eastern Uganda are specifically low in $\mathrm{N}, \mathrm{P}$ and $\mathrm{K}$ to meet the optimum requirements for crop growth. The situation is aggravated by inability of farmers to apply mineral fertilizers owing to highly prohibitive costs (Tenywa et al., 1999). Incorporation of crop residues into soil has the potential to provide a balanced supply of plant nutrients for crops (Hegde, 1998; Deshmukh et al., 2002).

Crop residues have a significant amount of organic matter and plant nutrients (Surekha et al., 2003). However, crop residue benefits are only realized upon their decomposition and subsequent nutrient release which are influenced by their biochemical quality (Mubarak et al., 2002; Igbal, 2009). The quality of crop residues as a source of nutrients for plants depends on their nutrient concentration and amounts released on decomposition (Mwangi et al., 2013). Decomposition of plant residues is influenced by critical levels of C, N and P (Cleveland et al., 2007). At the initial stages of decomposition of plant residues, $\mathrm{N}$ and $\mathrm{P}$ are not usually readily available to meet requirements of agents of decomposition. Consequently, available $\mathrm{N}$ and $\mathrm{P}$ in the soil may be immobilized by the agents of decomposition. These are then only released when their concentrations in the plant residues reach critical levels to enable transition from immobilization to mineralization (Berg et al., 2003; Moore et al., 2006; Parton et al., 2007). 
Finger millet, sorghum, cowpea and groundnut crop residues produced by farmers in north eastern Uganda are neither fed to livestock nor applied to crop fields. Instead, they are burnt at the patio where they are usually collected after threshing. Crop residues added to the soil decompose and release significant levels of nutrients such as N, P and K (Scagnozzi, 1997; Bauder, 2000). However, inadequate information exists regarding the value of groundnut shells and husks of finger millet, sorghum and cowpea as sources of plant nutrients for crop production in north eastern Uganda. Consequently, studies were conducted to determine the chemical composition, decomposition and nutrient release rates of millet, sorghum, cowpea and groundnut crop residues in semi-arid north eastern Uganda.

\section{Materials and Methods}

\subsection{Study Site}

This study was conducted at the National Semi-Arid Resources Research Institute (NaSARRI), Serere, Uganda. NaSARRI is located at $0^{\circ} 32^{\prime} \mathrm{N}$ and $35^{\circ} 27^{\prime} \mathrm{E}$ at 1128 meters above sea level. The site experiences an average annual minimum temperature of $17.9^{\circ} \mathrm{C}$ and a maximum temperature of $29.4{ }^{\circ} \mathrm{C}$. It receives an average annual rainfall of $1000 \mathrm{~mm}$ with a bimodal distribution. The relative humidity ranges between $72 \%$ and $84 \%$. The months of January to February and June to July receive little precipitation. However, the months of March to May and August to November are generally wetter with significant precipitation.

\subsection{Treatments and Experimental Design}

The treatments comprised of groundnut shells and husks of sorghum, finger millet and cowpea, laid out in a randomized complete block design and replicated four times. Pot and litter bag technique was used for this study (Fosu et al., 2007). Finger millet, sorghum, cowpea and groundnut crop residues were air dried and crushed into small particles and $20 \mathrm{~g}$ of each crop residue was put in 16 separate litter bags measuring $20 \mathrm{~cm} \times 20 \mathrm{~cm}$ with $0.30 \mathrm{~mm}$ mesh. This constituted four sets of litter bags for each crop residue. Each of the four sets of litter bags containing each crop residue were placed in a plastic pot with a perforated base measuring $30 \mathrm{~cm}$ diameter and height $25 \mathrm{~cm}$ and filled with $10 \mathrm{~kg}$ of high moor peat soil. The litter bags were placed vertically at $5 \mathrm{~cm}$ under the surface of the soil. A basin was placed underneath each pot and water level was maintained at 2-3 cm depth. The crop residues were incubated for four months. Four litter bags containing each crop residue were removed from each pot at a four-week interval and oven dried at $60{ }^{\circ} \mathrm{C}$ to constant weight and put in well labeled bags for laboratory analysis. The crop residues of finger millet, sorghum, cowpea and groundnut were got from seremi 2 , seso 3, secow 2 and serenut 2 crop varieties, respectively.

\subsection{Data Recording}

The non-decomposed and decomposed crop residues were analyzed for dry matter content, total organic carbon $(\mathrm{C})$, nitrogen $(\mathrm{N})$, phosphorus $(\mathrm{P})$, potassium $(\mathrm{K})$ and calcium $(\mathrm{Ca})$ at the Animal Science Laboratory-Makerere University. The percentage of dry matter loss for each crop residue was calculated using the equation: $\mathrm{M}_{1}(\%)=$ $\left[\left(\mathrm{M}_{0}-\mathrm{M}_{\mathrm{a}}\right) / \mathrm{M}_{0}\right] \times 100$; where $\mathrm{M}_{0}=$ initial crop residue dry mass before incubation, $\mathrm{M}_{\mathrm{a}}=$ the dry mass of crop residue remaining in the litter bag at sampling time during and at the end of incubation period and $\mathrm{M}_{1}=$ dry mass loss (Nahrawi et al., 2011). Total $\mathrm{N}$ was determined by the Kjeldahl procedure (Nelson \& Sommers, 2010), available $\mathrm{P}$ was determined using the Mehlich procedure and $\mathrm{K}$ was determined using the Flame photometry method. Calcium concentration in crop residues was determined by the titration procedure using standard EDTA solutions (Tucker et al., 1961). Organic carbon content in crop residues was determined using the dichromate oxidation procedure by Walkley-black (Nelson \& Sommers, 2010). The percentage of dry matter and nutrients remaining at each sampling stage during incubation was expressed as the ratio of the quantity of dry matter or nutrient at sampling to the initial content. The disappearance rate constants for dry matter were determined by getting the difference of dry matter quantity remaining between two successive sampling intervals over the incubation period. Similarly, the disappearance rate constant for nutrients was determined by getting the difference of nutrient quantity remaining between two successive sampling intervals over the incubation period (Njunie et al., 2004). Decomposing crop residues were sampled at four week intervals during 16 weeks' incubation period.

\subsection{Data Analysis}

Collected data were subjected to analysis of variance (ANOVA) using Genstat statistical package $13^{\text {th }}$ edition, 2013. The means were compared using the least significant difference (LSD) test at $p \leq 0.05$. Regression analysis was performed to determine the relationship between the crop residues, and $\mathrm{C} / \mathrm{N}$ ratio and $\mathrm{C} / \mathrm{P}$ ratio, respectively, and the release of $\mathrm{N}, \mathrm{P}, \mathrm{K}$, and Ca nutrients from crop residues. 


\section{Results}

3.1 Chemical Composition of Finger Millet, Sorghum, Cowpea and Groundnut Crop Residues Prior to Incubation

Finger millet husks had higher carbon (36.28\%) and nitrogen (3.46\%) contents and lower $\mathrm{C} / \mathrm{N}$ ratio $(10.45)$ than other crop residues (Table 1$)$, while cowpea husks had significantly $(\mathrm{P} \leq 0.05)$ higher $\mathrm{P}(0.60 \%)$ and $\mathrm{Ca}(0.30 \%)$ contents and lower $\mathrm{C} / \mathrm{P}$ ratio (57.23) than other crop residues (Table 1). Groundnut shells had significantly $(\mathrm{P} \leq$ $0.05)$ lower $\mathrm{P}(0.07 \%)$ and higher $\mathrm{K}(1.01 \%)$ compared to other crop residues whose $\mathrm{K}$ contents ranged from 0.33 to $0.55 \%$ (Table 1). Crop residues varied in carbon content in the order of finger millet $>$ cowpea $>$ groundnut $>$ sorghum, $\mathrm{N}$ content and $\mathrm{C} / \mathrm{N}$ ratio in the order of finger millet $>$ cowpea $>$ sorghum $>$ groundnut and $\mathrm{C} / \mathrm{P}$ ratio in the order of cowpea $>$ finger millet $>$ sorghum $>$ groundnut. Contents of $\mathrm{C}, \mathrm{N}, \mathrm{P}, \mathrm{K}$ and $\mathrm{Ca}$ in crop residues varied in the ranges of 32.08 to $36.28 \%, 1.80$ to $3.46 \%, 0.07$ to $0.60 \%, 0.33$ to $1.01 \%$ and 0.11 to $0.30 \%$, respectively. Carbon/nitrogen and C/P ratios of crop residues varied in the range of 10.45 to 17.94 and 57.23 to 469.0 , respectively.

Table 1. Chemical composition of crop residues before incubation of crop residues

\begin{tabular}{llllllll}
\hline Crop residue & Carbon (\%) & Nitrogen (\%) & C/N ratio & Phosphorus (\%) & C/P ratio & Potassium (\%) & Calcium (\%) \\
\hline Millet & 36.28 & 3.46 & 10.45 & 0.57 & 63.65 & 0.46 & 0.17 \\
Sorghum & 32.08 & 2.77 & 11.54 & 0.45 & 71.29 & 0.33 & 0.11 \\
Cowpea & 34.34 & 3.14 & 10.94 & 0.60 & 57.23 & 0.55 & 0.30 \\
Groundnut & 32.83 & 1.80 & 17.94 & 0.07 & 469.00 & 1.01 & 0.28 \\
\hdashline P-value & $<\mathbf{0 . 0 0 1}$ & $<\mathbf{0 . 0 0 1}$ & $<\mathbf{0 . 0 0 1}$ & $<\mathbf{0 . 0 0 1}$ & $<\mathbf{0 . 0 0 1}$ & $<\mathbf{0 . 0 0 1}$ & $<\mathbf{0 . 0 0 1}$ \\
LSD $(\mathbf{P} \leq \mathbf{0 . 0 5})$ & $\mathbf{0 . 0 1}$ & $\mathbf{0 . 0 6}$ & $\mathbf{0 . 2 3}$ & $\mathbf{0 . 0 8}$ & $\mathbf{0 . 0 5}$ & $\mathbf{0 . 0 5}$ & $\mathbf{0 . 0 1}$ \\
\hline
\end{tabular}

Note. $\mathrm{C} / \mathrm{N}=$ Carbon/nitrogen ratio and $\mathrm{C} / \mathrm{P}=$ Carbon/phosphorus ratio.

\subsection{Carbon, Nitrogen, Phosphorus, Potassium and Calcium Contents of Finger Millet, Sorghum, Cowpea and Groundnut Crop Residues at 4, 8, 12 and 16 Weeks after Incubation}

Crop residues were significantly different $(\mathrm{P} \leq 0.05)$ in $\mathrm{C}, \mathrm{N}$ and $\mathrm{K}$ contents at the different sampling stages during incubation (Table 2). However, crop residues varied significantly $(\mathrm{P} \leq 0.05)$ in $\mathrm{P}$ content at only 16 weeks after incubation (Table 2). In contrast, crop residues did not significantly vary $(\mathrm{P} \leq 0.05)$ in $\mathrm{Ca}$ content during incubation. Finger millet husks were significantly $(\mathrm{P} \leq 0.05)$ lower in $\mathrm{C}$ and $\mathrm{N}$ contents than other crop residues at most sampling stages; whereas groundnut shells were significantly $(\mathrm{P} \leq 0.05)$ higher in $\mathrm{C}, \mathrm{N}$ and $\mathrm{Ca}$ contents at most sampling stages than other crop residue treatments (Table 2). Sorghum husks retained significantly $(\mathrm{P} \leq$ 0.05) higher $\mathrm{P}$ levels than other crop residues at all stages of sampling (Table 2). Cowpea husks were significantly $(\mathrm{P} \leq 0.05)$ lower in $\mathrm{K}$ content than other crop residues at all stages of sampling, while $\mathrm{P}$ content was significantly $(\mathrm{P} \leq 0.05)$ lower at only 16 weeks after incubation (Table 2). Carbon, $\mathrm{N}, \mathrm{P}$ and $\mathrm{K}$ contents in crop residues showed a decreasing trend during incubation. Crop residues varied in $\mathrm{C}, \mathrm{N}, \mathrm{P}$ and $\mathrm{K}$ contents remaining after incubation in the order of groundnut $>$ sorghum $>$ cowpea $>$ finger millet, groundnut $>$ sorghum $>$ cowpea $>$ finger millet, sorghum $>$ finger millet $>$ groundnut $>$ cowpea and finger millet $>$ groundnut $>$ sorghum $>$ cowpea, respectively. 
Table 2. Carbon, N, P, K and Ca contents remaining in millet, sorghum, cowpea and groundnut crop residues at 4 , 8,12 and 16 weeks after incubation

\begin{tabular}{|c|c|c|c|c|}
\hline \multirow{2}{*}{ Crop residues/weeks of sampling } & \multicolumn{4}{|c|}{ Carbon (\%) } \\
\hline & 4 WAI & 8 WAI & 12 WAI & 16 WAI \\
\hline Millet & 25.9 & 16.1 & 13.81 & 10.22 \\
\hline Sorghum & 33.8 & 25.0 & 20.91 & 15.86 \\
\hline Cowpea & 38.0 & 25.1 & 17.79 & 15.55 \\
\hline Groundnut & 31.1 & 28.3 & 27.74 & 26.95 \\
\hline P-value & 0.023 & $\mathbf{0 . 0 3 8}$ & $<0.001$ & $<0.001$ \\
\hline \multirow[t]{2}{*}{ LSD $(P \leq 0.05)$} & 7.11 & 8.08 & 4.411 & 2.734 \\
\hline & \multicolumn{4}{|c|}{ Nitrogen (\%) } \\
\hline Millet & 0.44 & 0.39 & 0.34 & 0.29 \\
\hline Sorghum & 0.55 & 0.43 & 0.41 & 0.34 \\
\hline Cowpea & 0.48 & 0.40 & 0.35 & 0.30 \\
\hline Groundnut & 0.61 & 0.58 & 0.55 & 0.46 \\
\hline P-value & 0.021 & 0.001 & 0.001 & 0.007 \\
\hline \multirow[t]{2}{*}{ LSD $(P \leq 0.05)$} & 0.10 & 0.06 & 0.06 & 0.08 \\
\hline & \multicolumn{4}{|c|}{ Phosphorus (\%) } \\
\hline Millet & 0.78 & 0.68 & 0.58 & 0.47 \\
\hline Sorghum & 0.96 & 0.83 & 0.61 & 0.52 \\
\hline Cowpea & 0.67 & 0.49 & 0.38 & 0.27 \\
\hline Groundnut & 0.73 & 0.65 & 0.47 & 0.39 \\
\hline P-value & 0.150 & 0.138 & 0.199 & 0.05 \\
\hline \multirow[t]{2}{*}{ LSD $(P \leq 0.05)$} & NS & NS & NS & 0.18 \\
\hline & \multicolumn{4}{|c|}{ Potassium (\%) } \\
\hline Millet & 0.96 & 0.91 & 0.68 & 0.26 \\
\hline Sorghum & 0.64 & 0.51 & 0.28 & 0.19 \\
\hline Cowpea & 0.77 & 0.41 & 0.20 & 0.18 \\
\hline Groundnut & 0.96 & 0.65 & 0.53 & 0.21 \\
\hline P-value & $<0.001$ & $<0.001$ & $<0.001$ & $<0.001$ \\
\hline \multirow[t]{2}{*}{ LSD $(P \leq 0.05)$} & 0.01 & 0.01 & 0.01 & 0.03 \\
\hline & \multicolumn{4}{|c|}{ Calcium (\%) } \\
\hline Millet & 0.94 & 0.86 & 0.70 & 0.67 \\
\hline Sorghum & 0.88 & 0.80 & 0.71 & 0.57 \\
\hline Cowpea & 0.90 & 0.74 & 0.67 & 0.57 \\
\hline Groundnut & 0.92 & 0.79 & 0.75 & 0.73 \\
\hline P-value & 0.794 & 0.341 & $\mathbf{0 . 8 8 4}$ & 0.451 \\
\hline $\operatorname{LSD}(P \leq 0.05)$ & NS & NS & NS & NS \\
\hline
\end{tabular}

Note. $\mathrm{WAI}=$ weeks after incubation and $\mathrm{NS}=$ Not significant.

\subsection{Dry Matter of Millet, Sorghum, Cowpea and Groundnut Crop Residues Remaining at 4, 8, 12 and 16 Weeks during Incubation}

The remaining mass of millet, sorghum, cowpea and groundnut crop residues showed a significant $(\mathrm{P} \leq 0.05)$ relationship with time. The regression line of the remaining dry matter of crop residues best fitted a single exponential model and showed the extent to which the independent variable (time) influenced the dependent variable (remaining mass). Dry matter mass remaining showed a similar pattern for all the crop residues in that it declined faster at the initial phase of decomposition than towards the end of incubation (Figure 1). The exponential curve for millet had the highest coefficient of determination $\left(\mathrm{R}^{2}=0.9838\right)$ and decay rate constant $(\mathrm{K}=0.273)$ compared to other crop residues, while groundnuts had the lowest coefficient of determination $\left(\mathrm{R}^{2}=\right.$ $0.9551)$ and decay rate constant $(\mathrm{K}=0.048)$ compared to other crop residues (Figure 1). Crop residues had dry matter loss in the order of finger millet $>$ cowpea $>$ sorghum $>$ groundnuts (Figure 1). 

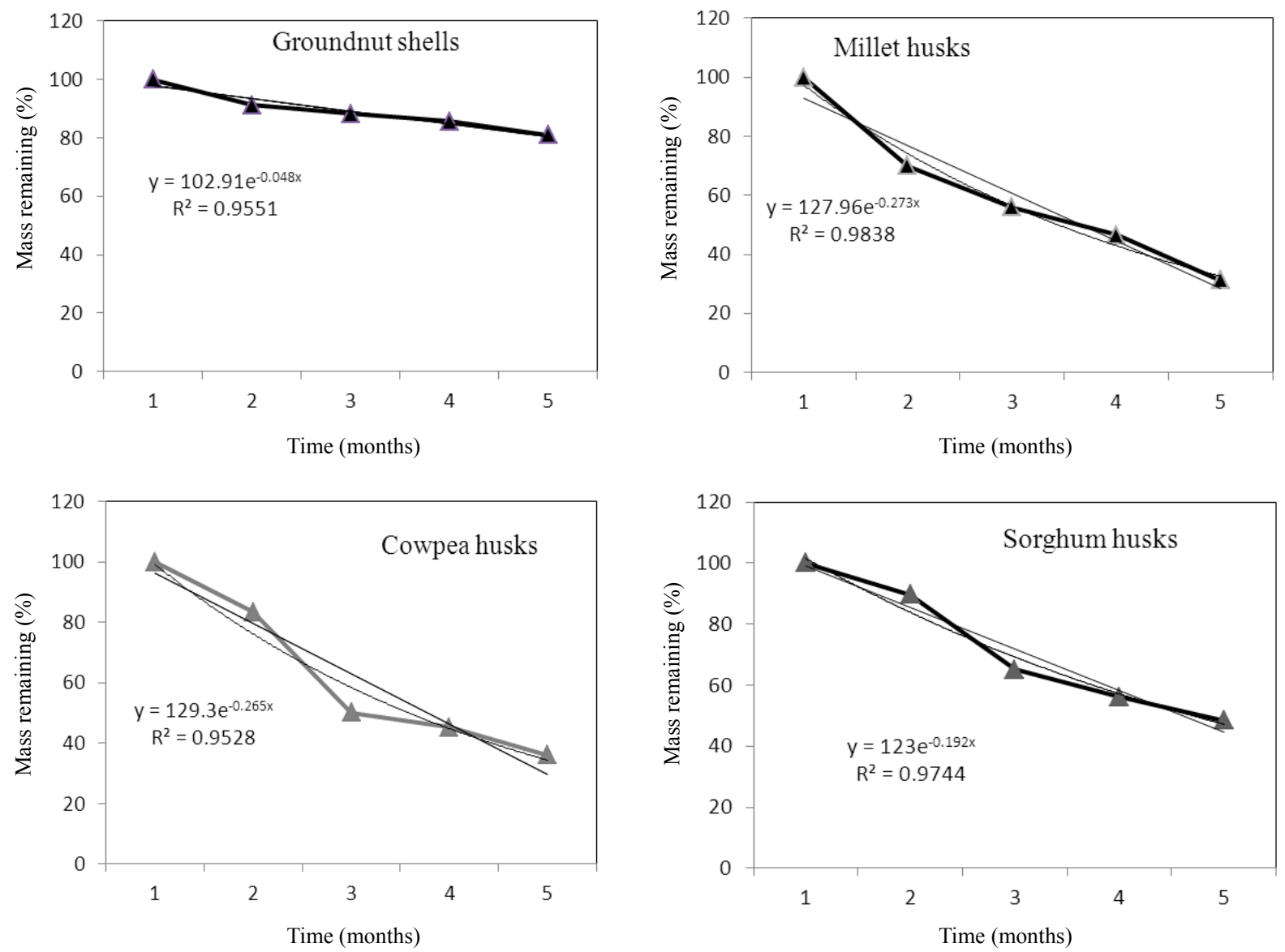

Figure 1. Dry matter remaining during decomposition of groundnut shells and husks of finger millet, sorghum and cowpea over time

3.4 Disappearance Rates of Dry Matter and Release Rates of Nitrogen, Phosphorus, Potassium, Calcium at 4, 8, 12 and 16 Weeks after Incubation

Crop residues differed significantly $(\mathrm{P} \leq 0.05)$ in dry matter, $\mathrm{N}$ and $\mathrm{K}$ disappearance rates at $4,8,12$ and 16 weeks after incubation (Table 3$)$. However, crop residues were not significantly variable $(\mathrm{P} \leq 0.05)$ in $\mathrm{P}$ and $\mathrm{Ca}$ disappearance rates at all sampling periods during incubation (Table 3). Finger millet husks had significantly ( $\mathrm{P}$ $\leq 0.05$ ) higher dry matter disappearance rates than all other crop residues at all sampling stages during incubation. In contrast, groundnut shells were significantly $(\mathrm{P} \leq 0.05)$ lower in dry matter disappearance rates than all other crop residues at all the sampling intervals (Table 3). At all the sampling intervals, finger millet husks had the highest $\mathrm{N}$ disappearance rates compared to all other crop residues (Table 3). Conversely, sorghum husks had significantly $(\mathrm{P} \leq 0.05)$ lower $\mathrm{N}$ disappearance rates than all other crop residues at all the sampling intervals (Table 3$)$. Potassium disappearance rates of sorghum husks were significantly $(\mathrm{P} \leq 0.05)$ higher than for other crop residues at 4 and 16-week sampling intervals; whereas $\mathrm{K}$ disappearance rates of cowpea husks were significantly $(\mathrm{P} \leq 0.05)$ higher than for all other crop residues at 8 and 12 -week sampling intervals. Finger millet husks had significantly $(\mathrm{P} \leq 0.05)$ the lowest $\mathrm{K}$ disappearance rates at all sampling periods compared to other crop residues. Crop residues showed similar disappearance patterns of $\mathrm{N}$ and $\mathrm{K}$, where both nutrients disappearance rates increased from the 4 th week up to the $16^{\text {th }}$ week (Table 3). Mean nutrient and dry matter disappearance rates in crop residues varied in the order: $\mathrm{K}>\mathrm{N}>\mathrm{P}>\mathrm{Ca}$ and finger millet $>$ cowpea $>$ sorghum $>$ groundnut respectively. Nitrogen, phosphorus and potassium release rates of crop residues occurred in the order of finger millet $>$ cowpea $>$ groundnut $>$ sorghum, cowpea $>$ groundnut $>$ finger millet $>$ sorghum and sorghum $>$ cowpea $>$ groundnut $>$ finger millet, respectively. 
Table 3. Dry matter disappearance and nutrient release rate constants $\left(\%\right.$ week $\left.^{-1}\right)$ of millet, sorghum, cowpea and groundnuts residues during 16 weeks of incubation

\begin{tabular}{|c|c|c|c|c|c|}
\hline \multirow{2}{*}{ Crop residues/weeks of sampling } & \multicolumn{5}{|c|}{ Dry matter (\%) } \\
\hline & 4 WAI & 8 WAI & 12 WAI & $16 \mathrm{WAI}$ & Mean \\
\hline Millet & 0.0219 & 0.0364 & 0.0475 & 0.0731 & 0.0447 \\
\hline Sorghum & 0.0065 & 0.0269 & 0.0361 & 0.0450 & 0.0286 \\
\hline Cowpea & 0.0122 & 0.0418 & 0.0498 & 0.0629 & 0.0417 \\
\hline Groundnut & 0.0055 & 0.0079 & 0.0098 & 0.0130 & 0.0009 \\
\hline Mean & 0.0115 & 0.0282 & $\mathbf{0 . 0 3 5 8}$ & 0.0485 & 0.0310 \\
\hline P-value & $<0.001$ & $<0.001$ & $<0.001$ & $<0.001$ & $<0.001$ \\
\hline \multirow[t]{2}{*}{ LSD $(P \leq 0.05)$} & 0.0017 & 0.0012 & 0.0006 & 0.0018 & 0.0013 \\
\hline & \multicolumn{5}{|c|}{ Nitrogen (\%) } \\
\hline Millet & 0.0855 & 0.0377 & 0.0455 & 0.0546 & 0.0558 \\
\hline Sorghum & 0.0530 & 0.0057 & 0.0089 & 0.0215 & 0.0223 \\
\hline Cowpea & 0.0584 & 0.0307 & 0.0376 & 0.0503 & 0.0443 \\
\hline Groundnut & 0.0648 & 0.0283 & 0.0316 & 0.0436 & 0.0421 \\
\hline Mean & 0.0654 & 0.0256 & 0.0309 & 0.0425 & 0.0411 \\
\hline P-value & $<0.001$ & 0.001 & $<0.001$ & 0.004 & 0.002 \\
\hline \multirow[t]{2}{*}{ LSD $(P \leq 0.05)$} & 0.0087 & 0.0093 & 0.0092 & 0.0154 & 0.0107 \\
\hline & \multicolumn{5}{|c|}{ Phosphorus (\%) } \\
\hline Millet & 0.0170 & 0.0256 & 0.0344 & 0.0487 & 0.0314 \\
\hline Sorghum & 0.0027 & 0.0117 & 0.0314 & 0.0414 & 0.0218 \\
\hline Cowpea & 0.0249 & 0.0479 & 0.0643 & 0.0875 & 0.0562 \\
\hline Groundnut & 0.0219 & 0.0295 & 0.0520 & 0.0616 & 0.0413 \\
\hline Mean & 0.0166 & 0.0287 & 0.0455 & 0.0598 & 0.0377 \\
\hline P-value & 0.181 & 0.732 & 0.185 & 0.897 & 0.499 \\
\hline \multirow[t]{2}{*}{ LSD $(P \leq 0.05)$} & NS & NS & NS & NS & NS \\
\hline & \multicolumn{5}{|c|}{ Potassium (\%) } \\
\hline Millet & 0.0024 & 0.0057 & 0.0244 & 0.0837 & 0.0291 \\
\hline Sorghum & 0.0272 & 0.0418 & 0.0803 & 0.1482 & 0.0744 \\
\hline Cowpea & 0.0166 & 0.0557 & 0.1008 & 0.1079 & 0.0703 \\
\hline Groundnut & 0.0023 & 0.0270 & 0.0397 & 0.0987 & 0.0419 \\
\hline Mean & 0.0121 & 0.0326 & 0.0613 & 0.1097 & 0.0539 \\
\hline P-value & $<0.001$ & $<0.001$ & $<0.001$ & $<0.001$ & $<0.001$ \\
\hline \multirow[t]{2}{*}{ LSD $(P \leq 0.05)$} & 0.0010 & 0.0011 & 0.0010 & 0.0010 & 0.0010 \\
\hline & \multicolumn{5}{|c|}{ Calcium (\%) } \\
\hline Millet & 0.0041 & 0.0098 & 0.0244 & 0.0292 & 0.0169 \\
\hline Sorghum & 0.0082 & 0.0147 & 0.0218 & 0.0471 & 0.0230 \\
\hline Cowpea & 0.0065 & 0.0193 & 0.0258 & 0.0367 & 0.0221 \\
\hline Groundnut & 0.0055 & 0.0152 & 0.0182 & 0.0195 & 0.0146 \\
\hline Mean & 0.0061 & 0.0148 & 0.0226 & 0.0331 & 0.0192 \\
\hline P-value & 0.791 & 0.342 & 0.875 & 0.497 & 0.626 \\
\hline LSD $(P \leq 0.05)$ & NS & NS & NS & NS & NS \\
\hline
\end{tabular}

Note. $\mathrm{NS}=$ not significant, $\mathrm{LSD}=$ least significant difference and $\mathrm{WAI}=$ weeks after incubation.

\subsection{Relationship between Decomposition and Nutrient Release Rates, and Carbon/Nitrogen Ratio of Crop Residues}

Linear regression curves between $\mathrm{C} / \mathrm{N}$ ratio and disappearance rates of $\mathrm{N}, \mathrm{P}$ and $\mathrm{K}$ showed negative relationships (Figure 2a). Linear regression analysis revealed that dry matter disappearance and nutrient release rates increased with decline in $\mathrm{C} / \mathrm{N}$ ratio (Figures $2 \mathrm{a}$ and $2 \mathrm{~b}$ ). In contrast, linear regression analysis showed that $\mathrm{Ca}$ release rate was not significantly $(\mathrm{P}<0.05)$ affected by $\mathrm{C} / \mathrm{N}$ ratio (Figure $2 \mathrm{a})$. The regression coefficients between $\mathrm{C} / \mathrm{N}$ ratio 
and $\mathrm{N}$ release rate $\left(\mathrm{R}^{2}=0.515^{*}\right)$ and $\mathrm{C} / \mathrm{N}$ ratio and dry matter disappearance rate $\left(\mathrm{R}^{2}=0.718^{*}\right)$ were higher than for $\mathrm{K}\left(\mathrm{R}^{2}=0.023\right), \mathrm{P}\left(\mathrm{R}^{2}=0.0169\right)$ and $\mathrm{Ca}\left(\mathrm{R}^{2}=0.00064\right)$ release rates (Figures $2 \mathrm{a}$ and $2 \mathrm{~b}$ ).

3.6 Relationship between Dry Matter Disappearance and Nutrient Release Rates, and Carbon/Phosphorus Ratio of Crop Residues

Linear regression curves between $\mathrm{C} / \mathrm{P}$ ratio and disappearance rates of $\mathrm{Ca}$ and dry matter showed negative relationships (Figures $3 \mathrm{a}$ and $3 \mathrm{~b}$ ). Linear regression analysis revealed that dry matter disappearance and $\mathrm{Ca}$ release rates increased with decline in $\mathrm{C} / \mathrm{P}$ ratio (Figures $3 \mathrm{a}$ and $3 \mathrm{~b}$ ), while $\mathrm{N}, \mathrm{P}$ and $\mathrm{K}$ were not affected by changes in $\mathrm{C} / \mathrm{P}$ ratio. Linear regression analysis showed that $\mathrm{C} / \mathrm{P}$ ratio significantly $(\mathrm{P} \leq 0.05)$ affected dry matter disappearance rate, but had no significant effect on N, P, K and Ca release rates (Figure 3b). The regression coefficients between $C / P$ ratio and dry matter disappearance rate $\left(\mathrm{R}^{2}=0.830^{*}\right)$ was higher than for $\mathrm{N}\left(\mathrm{R}^{2}=\right.$ $0.017), P\left(R^{2}=0.009\right), K\left(R^{2}=0.012\right)$ and $C a\left(R^{2}=0.007\right)$ release rates (Figures $3 a$ and $\left.3 b\right)$.
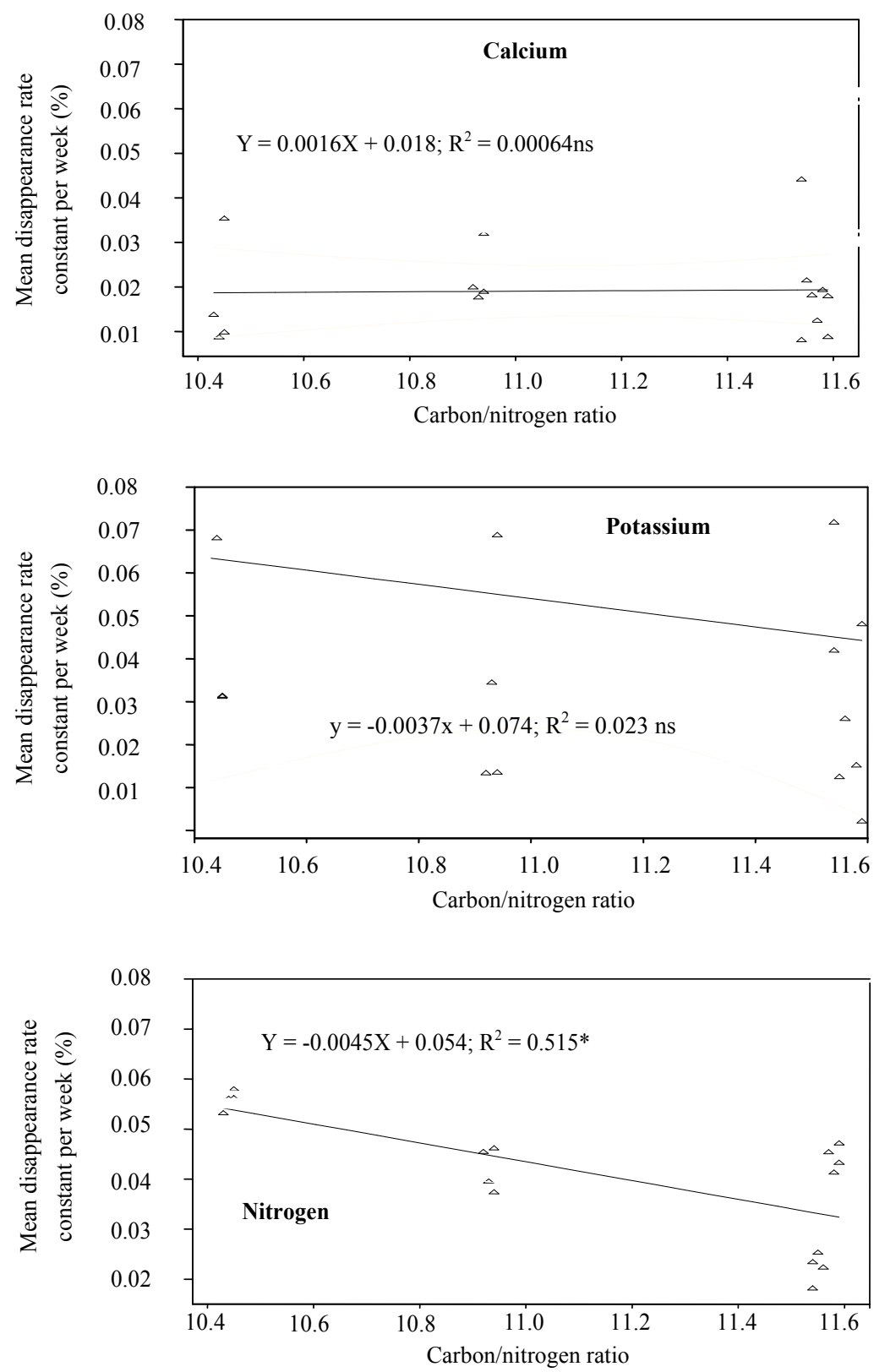


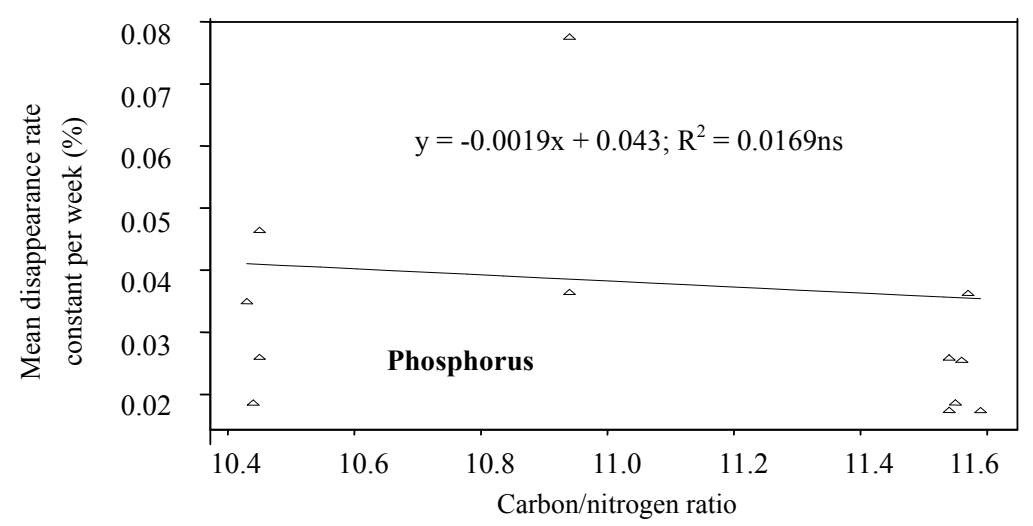

Figure 2a. Linear regression curves showing relationships between nutrient release rates and carbon/nitrogen ratio

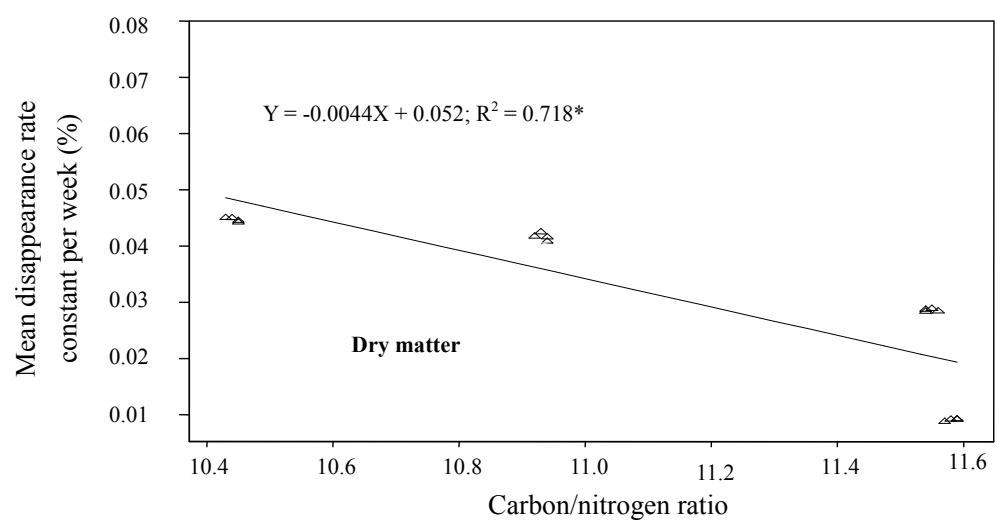

Figure $2 b$. Linear regression curves showing the relationship between dry matter disappearance rates and carbon/nitrogen ratio

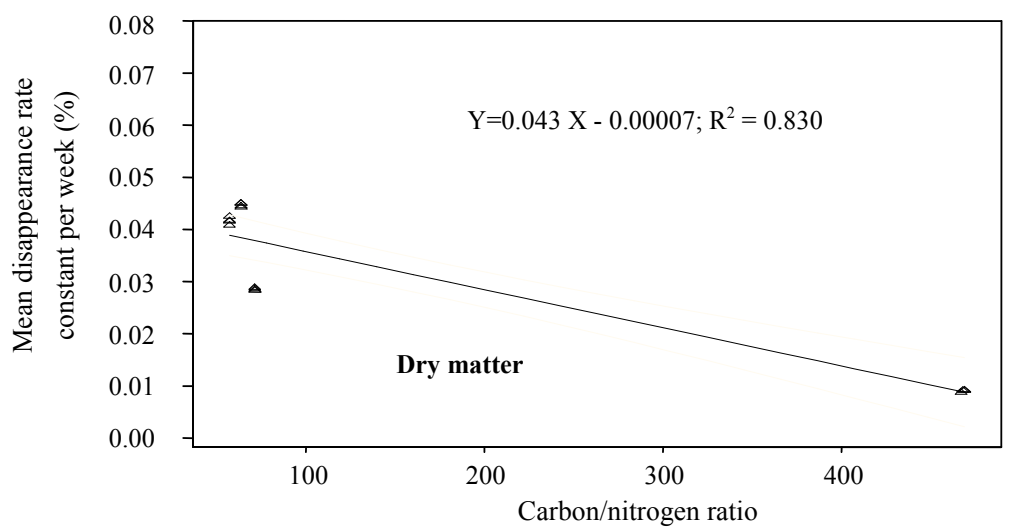

Figure 3a. Linear regression curves showing the relationship between dry matter disappearance rates and carbon/phosphorus ratio 

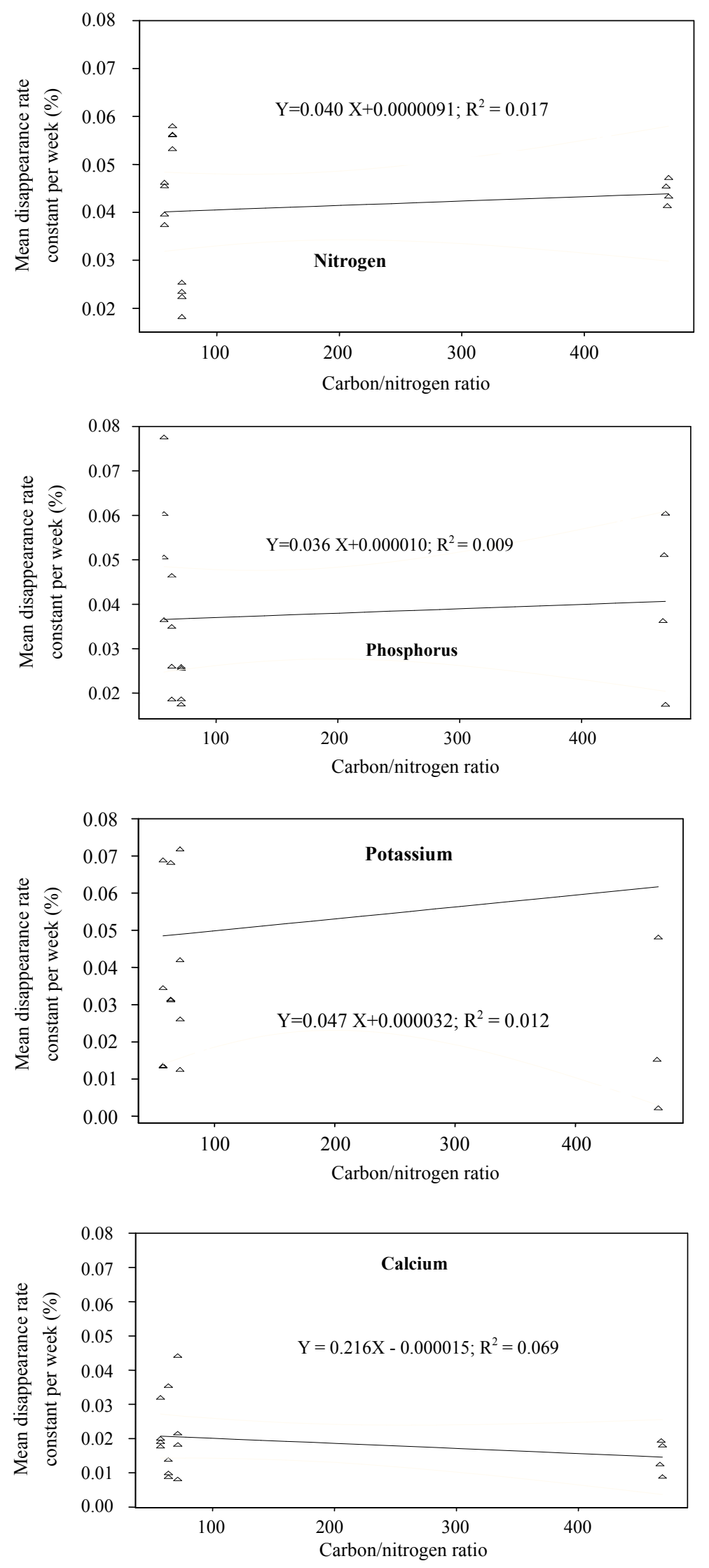

Figure $3 \mathrm{~b}$. Linear regression curves showing the relationship between nutrient release rates and carbon/phosphorus ratio 


\section{Discussion}

Finger millet, sorghum and cowpea husks had initial $\mathrm{N}$ and $\mathrm{P}$ levels in the range of 2.8 to $3.5 \%$ and 0.45 to $0.60 \%$, respectively. These figures are above the critical levels of $\mathrm{N}(2.5 \%)$ and $\mathrm{P}(0.12$ to $0.19 \%)$ required for the plant residues to transit from immobilization to mineralization (Hoorman et al., 2010). The $\mathrm{C} / \mathrm{N}$ and $\mathrm{C} / \mathrm{P}$ ratios of 10.45 to 11.54 and 57.23 to 71.29 of the three crop residues were below the critical values of $20: 1$ and $300: 1$, respectively, required for plant residues to transit from immobilization to mineralization (Hoorman et al., 2010). Therefore, it is evident that the three crop residues had the potential to decompose faster than groundnut shells that had $\mathrm{P}$ content $(0.07 \%)$ below the critical level of 0.12 to $0.19 \%$ and $\mathrm{C} / \mathrm{P}$ ratio above the critical level of 300:1 required for the plant residues to transit from immobilization to mineralization (Darrell., 2013). The low $\mathrm{P}$ level in groundnut shells causes initial immobilization of nutrients during incubation resulting in a low decomposition rate. Previous reports indicate that plant residues with low biochemical quality tend to initiate decomposition slowly due to immobilization of nutrients especially $\mathrm{N}$ at the early phase of their decomposition (Baggie et al., 2005; Fosu et al., 2007).

Groundnut shells and husks of finger millet, sorghum and cowpea differed significantly in C, N, P, K and Ca levels at different sampling stages during incubation. This is most likely due to differences in their nutrient release rates caused by the differences in their biochemical quality, and $\mathrm{C} / \mathrm{N}$ and $\mathrm{C} / \mathrm{P}$ ratios. Song et al. (2012), Kriauciuniene et al. (2012) and Munthali et al. (2015) reported that initial N and P concentrations in leaf litter, and $\mathrm{C} / \mathrm{N}$ and $\mathrm{C} / \mathrm{P}$ ratios were the most critical variables in influencing decomposition of plant residues. Finger millet husks had significantly lower concentration of $\mathrm{N}(0.29 \%)$ and $\mathrm{C}(10.22 \%)$ at the end of incubation than other crop residues, while groundnut shells had significantly higher organic $\mathrm{C}$ and $\mathrm{N}$ remaining at the end of incubation compared to other crop residues. This is an indication that finger millet husks decomposed and released $\mathrm{C}$ and $\mathrm{N}$ faster, while groundnut shells decomposed and released $\mathrm{C}$ and $\mathrm{N}$ slowly during incubation. This is further informed by a higher coefficient of determination $\left(\mathrm{R}^{2}=0.9838\right)$ and decomposition rate constant $(\mathrm{K}=0.273)$ of finger millet than other crop residues, while groundnut shells with a lower coefficient of determination $\left(\mathrm{R}^{2}=0.9551\right)$ and decomposition rate constant $(\mathrm{K}=0.048)$ compared to other crop residues shows that it decomposes slowly. The faster decomposition of finger millet is attributable to its higher initial $\mathrm{N}$ and lower $\mathrm{C} / \mathrm{N}$ ratio relative to other crop residues, while groundnut shells with a slower decomposition rate is attributable to its lower initial $\mathrm{N}$ and higher $\mathrm{C} / \mathrm{N}$ ratio relative to other crop residues. Cowpea husks had significantly lower $\mathrm{P}(0.27 \%)$ and $\mathrm{K}(0.18 \%)$ remaining at the end of incubation compared to other crops, and followed finger millet husks in $\mathrm{C}(15.55 \%)$ and $\mathrm{N}(0.30 \%)$ remaining at the end of incubation. This shows that cowpea husks are faster in releasing $\mathrm{P}$ and $\mathrm{K}$ during decomposition than other crop residues, and also relatively faster in the release of $\mathrm{C}$ and $\mathrm{N}$ during decomposition than sorghum husks and groundnut shells. This could be a consequence of its high initial $\mathrm{N}(3.14 \%)$ and $\mathrm{P}(0.60 \%)$ that could have reduced its $\mathrm{C} / \mathrm{N}$ and $\mathrm{C} / \mathrm{P}$ ratios. Bauder et al. (2000) and Fosu et al. (2007) reported that higher $\mathrm{C} / \mathrm{N}$ ratio tends to slow down decomposition and nutrient release by plant residues resulting in high amounts of nutrients remaining over a long time. Sorghum had significantly lower K $(0.19 \%)$ remaining at the end of incubation than finger millet husks and groundnut shells. This could be attributed to its lower initial K content $(0.33 \%)$ than other crop residues.

Dry matter content and levels of N, P and K in millet, sorghum, cowpea and groundnut crop residues decreased with increase in incubation. This could be attributable to mineralization. Scagnozzi et al. (2009) reported that during decomposition of plant residues $\mathrm{N}, \mathrm{P}$ and $\mathrm{K}$ nutrients are released and dry matter loss occurs. The quantity of dry matter of crop residues remaining declined faster at the initial phase of incubation as observed on Figure 1. This could be attributed to the presence of high levels of labile materials that are susceptible to microbial degradation during the initial phase of incubation and accumulation of recalcitrant substances in the later phases of incubation that are resistant to microbial breakdown. Baker et al. (2001) and Jacob et al. (2010) reported that litter decomposes faster at initial phase due to its good biochemical quality and slows down with time due to accumulation of recalcitrant compounds.

Linear regression analysis showed an inverse relationship between crop residue $\mathrm{C} / \mathrm{N}$ ratio and dry matter disappearance rates as well as $\mathrm{N}, \mathrm{P}, \mathrm{K}$ release rates. It similarly showed an inverse relationship between crop residue $\mathrm{C} / \mathrm{P}$ ratio and $\mathrm{Ca}$ release, and dry matter disappearance rates. This implies that during the decomposition of crop residues, a slower release of N, P and K occurs at higher $\mathrm{C} / \mathrm{N}$ ratios than at lower $\mathrm{C} / \mathrm{N}$ ratios. Similarly, a higher crop residue $\mathrm{C} / \mathrm{P}$ ratio results in slower release of $\mathrm{Ca}$ than from a lower crop residue $\mathrm{C} / \mathrm{P}$ ratio (Kriauciuniene et al., 2012). Non-negative linear regression relationship between $\mathrm{C} / \mathrm{N}$ ratio and $\mathrm{Ca}$ release rate and between $\mathrm{C} / \mathrm{P}$ ratio and $\mathrm{N}, \mathrm{P}$ and $\mathrm{K}$ release rates could possibly mean that $\mathrm{Ca}$ release is only influenced by $\mathrm{C} / \mathrm{P}$ ratio, while $\mathrm{N}, \mathrm{P}$ and $\mathrm{K}$ are only affected by $\mathrm{C} / \mathrm{N}$ ratio. 


\section{Conclusion}

This study has demonstrated that finger millet husks and cowpea husks with higher $\mathrm{N}$ and $\mathrm{P}$ contents and lower $\mathrm{C} / \mathrm{N}$ ratio and $\mathrm{C} / \mathrm{P}$ ratios have a potential to supply higher amounts of $\mathrm{N}$ and $\mathrm{P}$ nutrients faster. This could be beneficial for fast growing and early planted crops. In contrast, groundnut shells with a lower $\mathrm{N}$ content, but higher $\mathrm{C} / \mathrm{N}$ ratio release nutrients slowly which would be beneficial for longer availability of the nutrients. Nitrogen is released faster than other nutrients during decomposition, while $\mathrm{Ca}$ is released slowly compared to other nutrients during decomposition. Under intercropping planting system, early maturing intercrops would benefit from nutrients released by finger millet and cowpea husks, while late maturing intercrops would benefit more from nutrients released by groundnut shells.

\section{References}

Baggie, I., Rowell, D. L., Robinson, J. S., \& Warren, G. P. (2005). Decomposition and phosphorus release from organic residues as affected by residue quality and added inorganic phosphorus. Agroforestry Systems, 63, 125-131. https://doi.org/10.1007/s10457-004-5131-5

Baker, T. T. B., Graeme, L. B., Conner, W. H., Meier, C. E., Stanturf, J. A., \& Burke, M. K. (2001). Leaf litter decomposition and nutrient dynamics in four southern forested flood plain communities. Soil Science Society American Journal, 65(4), 1334-1347. https://doi.org/10.2136/sssaj2001.6541334x

Bauder, J. (2000). Decomposition rate of cereal straw as affected by soil placement. Cereal Crop Residues and Plant Nutrients, Montana State University Communications Services.

Berg, B., \& McClaugherty, C. (2003). Plant litter: Decomposition, humus formation, carbon sequestration (p. 286). https://doi.org/10.1007/978-3-662-05349-2

Cleveland, C.C., and D. Liptzin. (2007). C: N: P stoichiometry in soil: Is there a "Redfield ratio" for the microbial biomass? Biogeochemistry, 85, 235-252. https://doi.org/10.1007/S10533-007-9132-0

Darrell, S. (2013). Field by field phosphorus. Farm Journal of Conservation and Machinery. Retrieved from http://www.agweb.com

Deshmukh, M. R., Jain, H. C., Duhoon, S. S., \& Goswami, U. (2002). Integrated nutrient Management in sesame fir kymore plateau zone of M.P. Journal of Oilseeds Research, 19(1), 73-75.

Elmahdi, A. R., EL-Amin, S. E. M., \&Ahmed, F. G. (2007). Effect of sowing date on the performance of sesame (Sesamum indicum L.). Africa Crop Science Conference Proceedings, 8, 1943-1946.

Engoru, P., \& Bashaasha, B. (2001). Constraints to the effective production and marketing of sesame. African Crop Science Conference Proceedings, Soroti, Uganda, November 5, 1998 (p. 715).

Fosu, M., Kuhne, R. F., \& Vlek, P. L. (2007). Mineralization and microbial biomass dynamics during decomposition of four leguminous residues. American Journal of Agricultural and Biological Sciences, 7, 632-637.

Hegde, D. M. (1998). Effect of integrated nutrient management on productivity and soil fertility in pearl millet-wheat cropping system. Indian Journal of Agronomy, 43(2), 580-7.

Hoorman, J. J. (2010). Understanding soil microbes and nutrient recycling. Agriculture and natural resources. SAG, Ohio State University, USA.

Iqbal, S. M. (2009). Effect of crop residue qualities on decomposition rates, soil phosphorus dynamics and plant phosphorus uptake (Thesis Ph.D, University of Adelaide, School of Earth and Environmental Sciences).

Jacob, M., Viedenz, K., Polle, A., \& Thomas, F. M. (2010). Leaf litter decomposition in temperate deciduous forest stands with a decreasing fraction of beech (Fagus sylvatica). Oecologia, 164(4), 1083-1094. https://doi.org/10.1007/s00442-010-1699-9

Kriauciuniene, Z., Velička, R., \& Raudonius, S. (2012). The influence of crop residues types on their decomposition rate in the soil: a litter bag study. Zemdirbyste Agriculture, 99(3), 227-236.

Moore, T. R., Trofymow, J. A., Prescott, C. E., Fyles, J., \& Titus, B. D. (2006). Patterns of carbon, nitrogen and phosphorus dynamics in decomposing foliar litter in Canadian forests. Ecosystems, 9, 46-62. https://doi.org/10.1007/s10021-004-0026-x

Mubarak, A. R., Rosenani, A. B., Anuar, A. R., \& Zauyah, S. (2002). Decomposition and nutrient release of maize stover and groundnut haulms under tropical field conditions of Malaysia. Community Soil Science and Plant Analysis, 33(3), 609-622. https://doi.org/10.1081/CSS-120002767 
Munthali, M. G., Gachene, C. K. K., Karanja, N. K., \& Sileshi, G. W. (2005). Decomposition rates and nutrient release patterns of tephrosia vogelii and tephrosia candida Residues in Malawi. International Journal of Plant Science and Ecology, 1(2), 26-35.

Mwangi, P. W., Chemining'wa, N. G., Mburu, M. W. K., \& Mureithi, J. G. (2013). Decomposition and nutrient release rates of selected legume residues in a cold semiarid environment of Kenya. International Journal of Agronomy and Agricultural Research, 3(2), 1-13.

Nahrawi, H., Husni, M. H. A., Othman, R., \& Bah, A. (2011). Decomposition of leaf and fine root residues of three different crop species in tropical peat under controlled conditions. Malaysian Journal of Soil Science, $15,63-74$.

Nelson, D. W., \& Sommers, L. E. (2010). Methods of soil analysis. Retrieved November 15, 2010, from http://www.aaslpsu.edu/soils.methods.htm

Njunie, M. N., Wagger, M. G., \& Luna-Orea, P. (2004). Residue decomposition and nutrient release dynamics from two tropical forage legumes in a Kenyan environment. Agronomy Journal, 96, 1073-1081. https://doi.org/10.2134/agronj 2004.1073

Parton, W., Silver, W. L., Burke, I. C., Grassens, L., Harmon, M. E., Currie, W. S., ... Fasth, B. (2007). Global-scale similarities in nitrogen release patterns during long-term decomposition. Science, 315, 361-364. https://doi.org/10.1126/science.1134853

Scagnozzi, A., Saviozzi, A., Levi-Minzi, R., \& Riffaldi, R. (1997). Nutrient release from decomposing crop residues in soil: A laboratory experiment. The American Journal of Alternative Agriculture, 12(1), 10-13. https://doi.org/10.1017/S0889189300007116

Surekha, K., Padma, K. A., \& Narayana, R. M. (2003). Crop residue management to sustain soil fertility and irrigated rice yields. Nutrient Cycling in Agroecosystems, 67(2), 145-154. https://doi.org/10.1023/A:10255 43810663

Tenywa, J. S., Kidoido, M., Nyende, P., Kasenge, V., Oryokot, J., \& Mbowa, S. (1999). Prospects and constraints of finger millet production in Eastern Uganda. African Crop Science Journal, 7, 563-578. https://doi.org/10.4314/acsj.v7i4.27751

Tucker, B. B., \& Kurtz, L. T. (1961). Calcium and magnesium determinations by EDTA titrations. Soil Science Society of America Proceedings, 25, 27-29. https://doi.org/10.2136/sssaj1961.03615995002500010016x

\section{Copyrights}

Copyright for this article is retained by the author(s), with first publication rights granted to the journal.

This is an open-access article distributed under the terms and conditions of the Creative Commons Attribution license (http://creativecommons.org/licenses/by/4.0/). 